\title{
Effect of Planting Date and Iba Concentration on Rooting Ability of Stem Cutting Of Fraser's Photinia (Photinia X Fraseri).
}

\author{
Y. H. Hammo ${ }^{1}$, B. Z. Abdul Kareem², M. I. Salih ${ }^{3}$ \\ 1(Hort. Dept., College of Agriculture and forestry/ Dohuk Univ., Iraq) \\ 2,3( Hort. Dept., College of Agriculture/ Salahalden Univ., Iraq)
}

\begin{abstract}
This study was carried out in the Agricultural College/ Salahalden University during the period between $I^{\text {st }}$ March, 2010 to $1^{\text {st }}$ August, 2010, to investigate the effect of planting dates ( $I^{\text {st }}$ Mar, $I^{\text {st }}$ Apr, $1^{\text {st }}$ May), and IBA concentrations $(0,2000,4000,6000,8000) \mathrm{mg}^{\mathrm{l}^{-1}}$ on rooting ability of stem cuttings of Fraser's photinia (Photinia $x$ fraseri). Results show that the best rooting percentage $60.93 \%$ and roots number are for cutting propagated in $1^{\text {st }} \mathrm{Apr}$, while the best superior increase in shoot growth number, leave number, and shoot dry weight was in $1^{\text {st }}$ May. 6000 and $8000 \mathrm{mg} \cdot \mathrm{l}^{-1}$ IBA causes significantly increase in rooting percentage 67.11, $68.33 \%$ comported with the less (control) $39.00 \%$. Also roots number increased significantly with IBA increase from 2000 to 4000, 6000, $8000 \mathrm{mg} \cdot \mathrm{l}^{-1}$ with increasing percentage 23.81, 33.33, 47.62, and $50.00 \%$ when compared with control; the highest significantly increase in mean length of longest roots reach $485.43 \%$ for $8000 \mathrm{mg} . \mathrm{l}^{-1}$ than control. Although 2000 and $4000 \mathrm{mg} . \mathrm{l}^{-1}$ IBA causes significantly increase in shoots growth number, all IBA concentration show significantly increase in leave number and root dry weight, while the 4000, $6000 \mathrm{mg} . l^{-1}$ concentration had significantly effect on shoot dry weight. The interaction between planting dates and IBA concentrations case significantly variance in all rooting parameters and the highest rooting percentage reach $72.00 \%$ for cutting treated with 4000, 6000, $8000 \mathrm{mg} . \mathrm{l}^{-1}$ and planted in $1^{\text {st }} \mathrm{Apr}$, and the highest shoots growth number and leave number 4.67, 13.33 from cutting treated with 2000, mg. $l^{-1}$ and planted in $1^{\text {st }}$ May.

Keywords: planting dates, IBA concentration, Fraser's photinia .
\end{abstract}

\section{Introduction}

Fraser's photinia (Photinia $\mathrm{x}$ fraseri) a member of the Rosaceae family is a popular, evergreen, woody shrub, with shades of red on new growth. It is a woody ornamental plant species in which vegetative propagation by traditional methods is inefficient since cuttings of this species have been shown to be difficultto-root (Dirr, 1990). some cultural practices as time of year, media temperature, light level, air temperature, misting, and plant growth regulators (PGRs) are often used to stimulate rooting (promote adventitious rooting which arise from any plant part other than by the normal development and ontogeny of the seedling root and its branches) and reduce the length of time needed to root stem cuttings (Hartmann et al, 2002). Fraser's photinia is One of them which is considered difficult to root without an exogenous root promoting (PGRs) (Bonaminio, and Blazich, 1983), which found that 5000, $10000 \mathrm{mg} .1^{-1}$ of IBA solutions applied to terminal, semi-hardwood cuttings of Fraser's photinia (Photinia $x$ fraseri) promoted rooting more effective than control, and increase rooting percentage significantly $(100.0,93.3,30.0) \%$ for $10000,5000,0 \mathrm{mg} . \mathrm{l}^{-1} \mathrm{IBA}$, respectively, and number of roots per cutting. Fox and Montague, (2004) found that Rooting percentage of Fraser's photinia was highest for cuttings treated with high Drought Conditioning (DC) and plant growth regulators (PGR) treatments, while medium or high Drought Conditioning and plant growth regulators treatment produced the greatest number of roots, and the mean root length was longest for cuttings treated with medium + PGR and high DC + no PGR. Smythe and Smythe, (1989) indicated that a period is starting from October to November causes rooting percentage drops to an unacceptably low level, this being maintained until the end of summer for four ornamental plants Corokia cotoneaster, Cassinia albida, Pittosporum tenuifolium and Pseudopanax lessonii propagated by terminal cutting. Biasi et al (1990) found that the highest rooting percentage of semi-hardwood cuttings of Actinida deliciosa was obtained from cuttings collected in July - August and treated with 2000 $6000 \mathrm{mg} . \mathrm{I}^{-1}$ IBA. While optimum rooting of Cephalolaxus horringtonia cuttings occurred when the cutting treated with $10000 \mathrm{mg} . \mathrm{l}^{-1}$ of IBA as quick-dip method and planted during December to March with 88, 90, 78, and $70 \%$ rooting percentage respectively. Also Roots number and length were highest during these months (South worth and Dirr, 1994). Higher concentrations of IBA were more effective in promoting rooting ability in fall than in spring (Montgomery et al., 1994). Conden, (2002) taken stem cuttings of Castanopsis sclerophylla at three dates representing three growth stage (softwood, semi-hardwood, or hardwood), treated with IBA from 0 to $10000 \mathrm{mg} . \mathrm{l}^{-1}$. The response of softwood cuttings to IBA was quadratic with the greatest rooting $63 \%$ at 7500 mg. $1^{-1}$. However, roots number and length were not significantly affected by IBA concentrations, Bonaminio, and Blazich, (1983) Indicates that rooting Fraser's photinia cuttings during November may improved when compared with cuttings that taken in August. Hammo et al, (2009) found that Increase IBA from 750 to 3000 
mg.l-1 concentration causes significantly increase in rooting percentage of shoot tip cutting of Myrtus communis when compared with other treatments, also increase this factor from 2250 to $3750 \mathrm{mg} .1-1$ concentration causes significantly increase in total roots length, roots dry weight, shoots number.

The following study was undertaken to investigate the effects IBA application and planting dates on the rooting of Fraser's photinia stem cuttings.

\section{Material and methods}

This study was carried out in the plastic house of Oz-has nursery Salahalden governorate from $1^{\text {st }}$ March, 2010 to $1^{\text {st }}$ August, 2010, to investigate the effect of planting date, IBA concentrations on rooting ability of stem cuttings of Fraser's photinia (Photinia x fraseri). Hardwood cuttings, each $15 \pm 2 \mathrm{~cm}$ long of Fraser's photinia were planted on (1-Mar, 1-Apr, 1-May), from stock plants growing under uniform climate, The $5 \mathrm{~cm}$ leaves basal portion of each cutting removed and dipped in to $(0,2000,4000,6000,8000) \mathrm{mg}^{-1} 1^{-1}$ concentrations of IBA solution to a depth of $2 \mathrm{~cm}$ (quick deep). Each five treated cuttings were cultivated into $780 \mathrm{~cm}^{3}$ polyethylene propagating container filled with 2:1:1 river soli: peatmose: sand (by volume). The experimental design was a randomized complete block design using 5 cuttings per treatment and 4 replications. Thirteen weeks after the experiment was initiated, cuttings were harvested and data recorded include Rooting percentage $\%$, Mean number of roots/cutting, Mean length of longest root $(\mathrm{cm})$, Number of shoots/cutting, leave number/cutting, dry weight of shoots per cutting (gm), Dry weight of roots (gm)/cutting. The statistical analysis and Means comparison was done by using Duncan's Multiple Ranges Test under 5\% (SAS, 2001).

\section{Results and Discussion}

1- Effect of planting date and IBA on rooting percentage, roots number, and taller roots length, of Fraser's photinia cutting.

Data in table (1) show that hardwood cutting propagated in $1^{\text {st }}$ Apr had superior increase in rooting percentage $60.93 \%$ when compared with that propagate in $1^{\text {st }}$ Mar and $1^{\text {st }}$ May $55.00 \%, 56.80 \%$ respectively, although planting date had no significant effect on mean length of longest roots as shown in the previous table, the roots number in $1^{\text {st }}$ Apr and $1^{\text {st }}$ May increased significantly as compared with $1^{\text {st }}$ Mar with increasing percentage reach $34.21 \%, 27.63 \%$ for the two date respectively. IBA concentrations 6000 and $8000 \mathrm{mg} . \mathrm{l}^{-1}$ causes significantly increase in rooting percentage $67.11,68.33 \%$ respectively when compared with the less (control) $39.00 \%$ and $2000,4000 \mathrm{mg} .1^{-1}$ that gives $51.44 \%$, and $62.00 \%$ respectively. Also the roots number increased significantly with all IBA concentration when compared with control with increasing percentage reaches $23.81,33.33,47.62,50.00 \%$ for $2000,4000,6000,8000 \mathrm{mg} .1^{-1}$ respectively, the highest significantly increase in mean length of longest roots obtained for $8000 \mathrm{mg} .1^{-1}$ than control which reach $485.43 \%$. The interaction between planting date and IBA concentration case significantly deference in all rooting parameters ,the highest rooting percentage $72.00,72.00,72.00 \%$ obtained from cutting treated with 4000, 6000, 8000 mg..$^{-1}$ respectively and planted in $1^{\text {st }}$ Apr while the lowest percentage for control that planted in the $1^{\text {st }}$ Mar, and $1^{\text {st }}$ Apr $35.00 \%$ for the two. The interaction between all treated cutting planted in $1^{\text {st }}$ Apr, $1^{\text {st }}$ May and 8000 mg. $1^{-1}$ for the first planting date gives the highest means $3.00-4.17$ roots/cutting that varied significantly than other treatment, also the cuttings planted in the three planting date and treated with $8000 \mathrm{mg} . \mathrm{l}^{-1}$ of IBA give the highest mean length of longest roots $4.60,5.50,4.63 \mathrm{~cm}$ for $1^{\text {st }}$ May, $1^{\text {st }}$ Apr, $1^{\text {st }}$ May respectively while the less mean length are for control cutting that planted in $1^{\text {st }}$ Mar, and $1^{\text {st }}$ Apr $0.95,0.75 \mathrm{~cm}$.

\section{2- Effect of planting date and IBA on shoot growth number, leave number, shoots dry weight, roots dry weight of Fraser's photinia cutting.}

Data in table (2) show that cutting planted in $1^{\text {st }}$ May had superior increase in shoot growth number, leave number, and shoot dry weight when compared with another planting date with increasing percentage $23.73,10.07,9.08 \%$ than $1^{\text {st }}$ Apr and 49.39, 54.00, 25.24\% than $1^{\text {st }}$ Mar for the three characters respectively, while this factor had no significant effect on root dry weight. IBA concentrations 2000 and $4000 \mathrm{mg} . \mathrm{l}^{-1}$ causes significantly increase in shoots growth number 3.89, 3.75 than other treatment and the less number was for control 2.67, all IBA concentration show significantly increase in leave number when compared with control with increasing percentage reaches $26.95,26.24,21.28,20.57 \%$ for $2000,4000,6000,8000 \mathrm{mg}^{-1} \mathrm{l}^{-1}$ respectively and in root dry weight with increasing percentage $22.70,22.63,42.81,33.68 \%$ respectively, while the 4000 , $6000 \mathrm{mg} . \mathrm{l}^{-1}$ concentration of IBA had significantly effect on shoot dry weight more than other treatment. The interaction between planting date and IBA concentration case significantly deference in all rooting parameters in table (2), and the highest shoots growth number and leave number are 4.67, 13.33 that obtained from cutting treated with 2000, mg. $1^{-1}$ and planted in $1^{\text {st }}$ May while the lowest are for control 2.00, 6.00 that planted in the $1^{\text {st }}$ Mar for the two character respectively. the interaction between cutting planted in $1^{\text {st }}$ May and $2000 \mathrm{mg} .1^{-1}$ give the highest means of shoots dry weight 3.25 gm that varied significantly than other treatment, also the cuttings planted in most planting date and treated with all IBA concentration give the highest mean of root dry weight 
this character ranged between 0.37- $0.49 \mathrm{gm}$ while the less mean are for control cutting that planted in $1^{\text {st }}$ Mar $0.25 \mathrm{gm}$. The significantly superior of $1 \mathrm{st}$ Apr and $1 \mathrm{st}$ May in most studies characters may be related to the Optimum daytime in this month which was satisfactory for rooting cutting of most temperate species (Hartmann et al. 2002).or may be refer to the positive effect of IBA in hastening root initiation, increasing the number and quality of roots produced, and increasing the uniformity of rooting which would be capable of increased nutrient and water uptake (Blazich, 1988 ; Bonaminio, and Blazich, 1983). Also the increases in all characters may be referring to the highly significant positive correlation between them as shown in table (3).

Table (1). Effect of planting date and IBA on rooting percentage and some root characters of Fraser's photinia cutting.

\begin{tabular}{|c|c|c|c|c|c|c|c|}
\hline \multirow{2}{*}{\multicolumn{2}{|c|}{ Planting Date }} & \multicolumn{5}{|c|}{ IBA concentrations $\mathrm{mg} \mathrm{l}^{-1}$} & \multirow{2}{*}{$\begin{array}{c}\text { Planting Date } \\
\text { Effect }\end{array}$} \\
\hline & & 0 & 2000 & 4000 & 6000 & 8000 & \\
\hline \multirow{4}{*}{$\begin{array}{l}0^{0} \\
0 \\
\Xi \\
0 \\
0 \\
0 \\
0\end{array}$} & $1^{\mathrm{st}}$ Mar & $35.00 \mathrm{~d}$ & $53.33 c$ & $52.00 \mathrm{c}$ & $67.33 \mathrm{ab}$ & \multirow{3}{*}{$\begin{array}{c}67.33 \\
a b \\
72.00 \\
a \\
65.67 \\
a b \\
\end{array}$} & $55.00 \mathrm{~b}$ \\
\hline & $1^{\text {st }} \mathrm{Apr}$ & $35.00 \mathrm{~d}$ & $53.67 \mathrm{c}$ & $72.00 \mathrm{a}$ & $72.00 \mathrm{a}$ & & $60.93 a$ \\
\hline & $1^{\text {st }}$ May & $47.00 \mathrm{c}$ & $47.33 c$ & $62.00 \mathrm{~b}$ & $62.00 \mathrm{~b}$ & & $56.80 \mathrm{~b}$ \\
\hline & IBA Effect & $39.00 \mathrm{~d}$ & $51.44 \mathrm{c}$ & $62.00 \mathrm{~b}$ & $67.11 \mathrm{a}$ & $\begin{array}{c}68.33 \\
\mathrm{a}\end{array}$ & \\
\hline \multirow{4}{*}{ 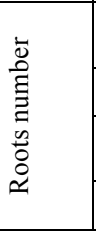 } & $1^{\text {st }}$ Mar & $2.17 \mathrm{~d}$ & $2.50 \mathrm{c}-\mathrm{d}$ & $2.33 \mathrm{~cd}$ & $2.67 \mathrm{c}-\mathrm{d}$ & $\begin{array}{c}3.00 \mathrm{a} \\
-\mathrm{d}\end{array}$ & $2.53 \mathrm{~b}$ \\
\hline & $1^{\text {st }}$ Apr & $2.50 \mathrm{c}-\mathrm{d}$ & $3.17 \mathrm{a}-\mathrm{d}$ & $3.50 \mathrm{a}-\mathrm{c}$ & $3.67 \mathrm{ab}$ & $4.17 \mathrm{a}$ & $3.40 \mathrm{a}$ \\
\hline & $1^{\text {st }}$ May & $2.33 \mathrm{~cd}$ & $3.00 \mathrm{a}-\mathrm{d}$ & $3.50 \mathrm{a}-\mathrm{c}$ & $4.00 \mathrm{a}$ & $\begin{array}{c}3.33 \mathrm{a} \\
-\mathrm{d}\end{array}$ & $3.23 \mathrm{a}$ \\
\hline & IBA Effect & $2.33 b$ & $2.89 \mathrm{ab}$ & $3.11 \mathrm{a}$ & $3.44 \mathrm{a}$ & $3.50 \mathrm{a}$ & \\
\hline \multirow{4}{*}{ 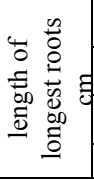 } & $1^{\text {st }}$ Mar & $0.95 \mathrm{~g}$ & $2.50 \mathrm{c}-\mathrm{e}$ & $2.25 \mathrm{de}$ & $3.57 \mathrm{~b}$ & $4.60 \mathrm{a}$ & $2.77 \mathrm{a}$ \\
\hline & $1^{\text {st }}$ Apr & $0.37 \mathrm{~g}$ & $2.50 \mathrm{c}-\mathrm{e}$ & $2.17 \mathrm{e}$ & $3.27 b-d$ & $5.50 \mathrm{a}$ & $2.76 \mathrm{a}$ \\
\hline & $1^{\text {st }}$ May & $1.20 \mathrm{fg}$ & $2.50 \mathrm{c}-\mathrm{e}$ & $2.07 \mathrm{ef}$ & $3.33 \mathrm{bc}$ & $4.63 \mathrm{a}$ & $2.75 \mathrm{a}$ \\
\hline & IBA Effect & $0.84 \mathrm{~d}$ & $2.50 \mathrm{c}$ & $2.16 \mathrm{c}$ & $3.39 \mathrm{~b}$ & $4.91 \mathrm{a}$ & \\
\hline
\end{tabular}

\section{References}

[1]. Biasi, R., G. Marino and G. Costa (1990). Propagation of Hayward Actinidia deliciosa from soft and semi-hardwood cuttings. ActaHort. 282: 243-250.

[2]. Blazich, F. A. (1988). Chemical and Formulations Used to Promote Adventitious Rooting, In: Davis, T. D., B. E. Haissig and N. Sankhla N, (Eds.). Adventitious Root Formation in Cuttings. Dioscorides Press, Portland, Ore. pp. $132-149$.

[3]. Bonaminio, V.P. and F.A. Blazich. (1983). Response of Fraser's photinia stem cuttings to selected rooting compounds. J. Environ. Hort. 1:9-11.

[4]. Conden, P. J. (2002). Propagation of Castanopsis sclerophylla and Lindera umbellata by stem cuttings and nutrition of containerized Ternstroemia gymnanthera. M.Sc. Thesis, N.C. State Univ. Raleigh.

[5]. Dirr, M.A. (1990). Effects of P-ITB and IBA on the rooting response of 19 landscape taxa. J. Environ. Hort. 8:83-85.

[6]. Dirr, M.A. (1998). Manual of Woody Landscape Plants: Their Identification, Ornamental Characteristics, Culture, Propagation and Uses.5th ed. Stipes Publishing, Champaign, IL.

[7]. Fox, L.; and T. Montague (2004). Short Term Drought Conditioning Influences Adventitious Rooting of Firebush and Fraser's Photinia Stem Cuttings, J. Environ. Hort. 22(3):144-148.

[8]. Hammo, Y. H., MAYI A. A. T., and SADEEQ J. A. (2009). Effect of Media and Indole Butyric Acid on Shoot Tip Cutting of Myrtus communis L. J. Duhok Unvi. 12 (2) 2009.

[9]. Hartmann, H.T., D.E. Kester, F.T. Davies, Jr., and R.L. Geneve. (2002). Plant Propagation: Principles and Practices. 7th ed. Prentice Hall. Upper Saddle River, NJ.

[10]. Montgomery, C., B. Behe, J. Eakes, and T. Krentz (1994). Cultivar and IBA concentration influence rooting of Buddleia. SNA Research Confernce.39: 36-39.

[11]. Smythe, C. J. and K. D. Smythe(1989). Identifying times of high potential rooting for cuttings of four common New Zealand native ornamentals. 368-369.www.scholar.google.com

[12]. Southworth, A. and M. A. Dirr (1994). The effects of timing and growth regulator treatment on the rooting of Cephalotaxus harringtonia. SNA research confernce.39: 293-295. 
Table (2).Effect of planting date and IBA on some vegetative characters of Fraser's photinia cutting.

\begin{tabular}{|c|c|c|c|c|c|c|c|}
\hline \multirow{2}{*}{\multicolumn{2}{|c|}{ Planting Date }} & \multicolumn{5}{|c|}{ IBA concentrations $\mathrm{mg} \mathrm{l}^{-1}$} & \multirow{2}{*}{$\begin{array}{c}\text { Planting Date } \\
\text { Effect }\end{array}$} \\
\hline & & 0 & 2000 & 4000 & 6000 & 8000 & \\
\hline \multirow{4}{*}{ 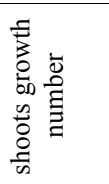 } & $1^{\text {st }}$ Mar & $2.00 \mathrm{e}$ & $3.00 \mathrm{~cd}$ & $3.00 \mathrm{~cd}$ & $2.67 \mathrm{~d}$ & $3.00 \mathrm{~cd}$ & $2.73 c$ \\
\hline & $1^{\text {st }} \mathrm{Apr}$ & $2.50 \mathrm{de}$ & $4.00 \mathrm{ab}$ & $4.00 \mathrm{ab}$ & $3.00 \mathrm{~cd}$ & $3.00 \mathrm{~cd}$ & $3.30 \mathrm{~b}$ \\
\hline & $1^{\text {st }}$ May & $3.50 \mathrm{bc}$ & $4.67 \mathrm{a}$ & $4.25 \mathrm{a}$ & $4.00 \mathrm{ab}$ & $4.00 \mathrm{ab}$ & $4.08 \mathrm{a}$ \\
\hline & IBA Effect & $2.67 \mathrm{c}$ & $3.89 \mathrm{a}$ & $3.75 \mathrm{a}$ & $3.22 \mathrm{~b}$ & $3.33 b$ & \\
\hline \multirow{4}{*}{ 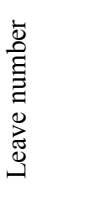 } & $1^{\text {st }}$ Mar & $6.00 \mathrm{~h}$ & $6.50 \mathrm{gh}$ & $6.50 \mathrm{gh}$ & $7.50 \mathrm{fg}$ & $9.00 \mathrm{de}$ & $7.10 \mathrm{c}$ \\
\hline & $1^{\text {st }} \mathrm{Apr}$ & $8.50 \mathrm{ef}$ & $10.00 \mathrm{~cd}$ & $11.17 \mathrm{bc}$ & $11.00 \mathrm{bc}$ & $9.00 \mathrm{de}$ & $9.93 b$ \\
\hline & $1^{\text {st }}$ May & $9.00 \mathrm{de}$ & $13.33 \mathrm{a}$ & $12.00 \mathrm{~b}$ & $10.00 \mathrm{~cd}$ & $10.33 \mathrm{~cd}$ & $10.93 \mathrm{a}$ \\
\hline & IBA Effect & $7.83 b$ & $9.94 \mathrm{a}$ & $9.89 \mathrm{a}$ & $9.50 \mathrm{a}$ & $9.44 \mathrm{a}$ & \\
\hline \multirow{4}{*}{ 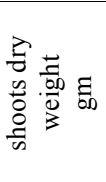 } & $1^{\text {st }} \mathrm{Mar}$ & $1.42 \mathrm{~g}$ & $1.71 \mathrm{~g}$ & $2.10 \mathrm{f}$ & $2.77 b-d$ & $2.91 \mathrm{a}-\mathrm{c}$ & $2.18 \mathrm{c}$ \\
\hline & $1^{\text {st }} \mathrm{Apr}$ & $1.75 \mathrm{~g}$ & $2.15 f$ & $3.07 \mathrm{ab}$ & $3.16 \mathrm{a}$ & $2.40 \mathrm{ef}$ & $2.50 \mathrm{~b}$ \\
\hline & $1{ }^{\text {st }}$ May & $2.59 \mathrm{c}-\mathrm{e}$ & $3.25 \mathrm{a}$ & $2.96 \mathrm{ab}$ & $2.52 \mathrm{de}$ & $2.34 \mathrm{ef}$ & $2.73 \mathrm{a}$ \\
\hline & IBA Effect & $1.92 \mathrm{~d}$ & $2.37 \mathrm{c}$ & $2.71 \mathrm{ab}$ & $2.81 \mathrm{a}$ & $2.55 b c$ & \\
\hline \multirow{4}{*}{ 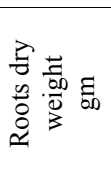 } & $1^{\text {st }}$ Mar & $0.25 \mathrm{~d}$ & $0.42 \mathrm{a}-\mathrm{c}$ & $0.36 \mathrm{a}-\mathrm{d}$ & $0.49 \mathrm{a}$ & $0.46 \mathrm{ab}$ & $0.39 \mathrm{a}$ \\
\hline & $1^{\text {st }} \mathrm{Apr}$ & $0.32 \mathrm{~cd}$ & $0.37 \mathrm{a}-\mathrm{d}$ & $0.41 \mathrm{a}-\mathrm{c}$ & $0.41 \mathrm{a}-\mathrm{c}$ & $0.34 b-d$ & $0.37 \mathrm{a}$ \\
\hline & $1^{\text {st }}$ May & $0.38 \mathrm{a}-\mathrm{d}$ & $0.37 \mathrm{a}-\mathrm{d}$ & $0.40 \mathrm{a}-\mathrm{c}$ & $0.46 a b$ & $0.47 \mathrm{ab}$ & $0.42 \mathrm{a}$ \\
\hline & IBA Effect & $0.32 b$ & $0.38 \mathrm{ab}$ & $0.39 \mathrm{a}$ & $0.45 \mathrm{a}$ & $0.42 \mathrm{a}$ & \\
\hline
\end{tabular}

Each means in row for one or interactions factors with different letters are significantly different at $\mathrm{P}$

$=0.05$ using Duncan's multiple range test.

Table (3): correlation between characters.

\begin{tabular}{|l|l|l|l|l|l|l|}
\hline \multicolumn{1}{|c|}{ characters } & $\begin{array}{l}\text { Rooting } \\
\%\end{array}$ & $\begin{array}{l}\text { Roots } \\
\text { number }\end{array}$ & $\begin{array}{l}\text { Length of } \\
\text { longest } \\
\text { roots }\end{array}$ & $\begin{array}{l}\text { shoots } \\
\text { number }\end{array}$ & $\begin{array}{l}\text { Leave } \\
\text { number } \\
\text { dry } \\
\text { weight }\end{array}$ \\
\hline Roots number & $0.551^{* *}$ & & & & & \\
\hline Length of longest roots & $0.757^{* *}$ & $0419^{* *}$ & & & & \\
\hline shoots number & 0.245 & $0.336^{*}$ & 0.178 & & & \\
\hline Leave number & $0.318^{*}$ & $0.510^{* *}$ & 0.148 & $0.773^{* *}$ & & \\
\hline shoots dry weight & $0.601^{* *}$ & $0.436^{* *}$ & $0.326^{*}$ & $0.539^{* *}$ & $0.748^{* *}$ & \\
\hline Roots dry weight & $0.509^{* *}$ & 0.165 & $0.451^{* *}$ & $0.324^{*}$ & 0.186 & $0.430^{* *}$ \\
\hline
\end{tabular}

